Bangladesh J. Bot. 40(2): 121-132, 2011 (December)

\title{
CLUSTER ANALYSIS OF SUBMONTANE FOREST ALONG WESTERN SLOPE OF FRASERS' HILL RESEARCH CENTRE IN RAUB DISTRICT, MALAYSIA
}

\author{
Jumaat H. Adam, Liow Kah Ming, Mohd Afiq Aizat Juhari, Masdahila Ahmad \\ Jalaludin, Wan Mohd Radzi Idris, ABD Rahim OThMan \\ aNd Siti Norhafizah AhMad TaRmidzi
}

\author{
School of Environmental \& Natural Resource Sciences, Faculty of Science \& Technology, \\ Universiti Kebangsaan Malaysia, 43600 UKM, Bangi, Selangor, Malaysia
}

Key words: Cluster analysis, Submontane forest, Western slope, Malaysia

\begin{abstract}
Submontance forest at five different altitudes along the western slope of Frasers' Research Centre (FHRC) in Raub District, Pahang State of Malaysia by Ward Linkage Method (WLM) was classified. Five plots were set at $1000 \mathrm{~m}(\mathrm{P} 1), 1050 \mathrm{~m}(\mathrm{P} 2), 1100 \mathrm{~m}(\mathrm{P} 3), 1150 \mathrm{~m}(\mathrm{P} 4)$ and $1200 \mathrm{~m}(\mathrm{P} 5)$, and all the trees with diameter at breast height $(\mathrm{DBH}) \geq 5 \mathrm{~cm}$ have been measured. Cluster analysis by WLM of these plots resulted in the identification of four forest zones (FZ) denoted by FZ1P1, FZ2P2, FZ3P3P4 and FZ4P5. These forest zones were denoted by three most dominant species in term of importance value $\left(\mathrm{I}_{\mathrm{v}}\right)$ such as Dacrydium elatum (Roxb.) Wall. ex Hook.- Prunus arborea (Blume) Kalkman - Adinandra dumosa Jack (Zone FZ1P1), Trigonobalanus verticillata Forman - Syzygium stapfianum (King) I.M. Turner - Syzygium subdecussatum (Wall. ex Duthie) I.M. Turner (Zone FZ2P2), Syzygium leptostemon (Korth.) Merr. \& L.M. Perry - Wikstroemia polyantha Merr - Syzygium napiforme (Koord. \& Valeton) Merr. \& L.M. Perry (Zone FZ3P3P4) and Syzygium filiforme (Wall. ex Duthie) P. Chantaranothai \& J. Parn.- Decaspermum parviflorum (Lam.) A.J. Scott - Litsea machilifolia Gamble (Zones FZ4P5). Correlation analysis showed that the number of trees in 0.1 ha, density/ha, DBH, mean DBH, number of species, number of family, number of genus, basal area (BA), mean BA, R, $\mathrm{H}$ and $\mathrm{E}$ and species with the biggest $\mathrm{DBH}$ decreased with increasing altitude. The $\mathrm{r}$-values obtained for these 13 attributes were from -0.13 to -0.99 . The distribution of trees were found to differ between DBH Class (DBHC) in all FZ. This study revealed that 73.1 to $88.17 \%$ of trees in all FZ fall into DBHC1 and DBHC2. On the other hand, 1.02 to $6.28 \%$ fall into DBHC5, DBHC6 and DBHC7. The distribution of species was different between $\mathrm{I}_{\mathrm{v}}$ Class $\left(\mathrm{I}_{\mathrm{v}} \mathrm{C}\right)$ all the four FZ. It was found that from 77.68 to $93.75 \%$ of the species fall into $\mathrm{I}_{\mathrm{v}} \mathrm{C} 1$ and $\mathrm{I}_{\mathrm{v}} \mathrm{C} 2$, and between 1.66 to $5.12 \%$ of the species fall into $\mathrm{I}_{\mathrm{v}} \mathrm{C} 4$ and $\mathrm{I}_{\mathrm{v}} \mathrm{C} 5$.
\end{abstract}

\section{Introduction}

Studies on changes in forest structures due to altitude increment along the slope of hill and montane tropical rain forest have been carried out (Adam 2001, 2000, Adam and Affandi 1993, 2000, Soepadmo 1987, Kochummen 1982). The application of clustering method using species similarity and density to classify diverse species composition along the slope of hill and montane tropical rain forests into different cluster groups have proved helpful (Adam et al. 2010, 2007, Adam 1997, Adam and Enning 1996, Adam and Zahiruddin 2005, Mahmud et al. 1992, Ohsawa et al. 1985).

This study was carried out along the western slope at Universiti Kebangsaan Malaysia (UKMS) FHRC that stood at altitude from 1000 to $1200 \mathrm{~m}$. The Bukit Fraser was formed by molten magma that extruded upon the earth crust as a result of tectonic activities 250 million ago, forming the main terrace of Peninsular Malaysia, Titiwangsa Range (Muhammad et al. 2009). The rainfall at these altitudes is approximately $2600 \mathrm{~mm} /$ year, daily temperature ranges from $18-22^{\circ} \mathrm{C}$ and relative humidity between 85 and 95\% (Adam and Maimon 2009). The forest of the study area is a transition between pristine hill dipterocarp forest at the lower section of the slope and lower montane forest or oak-laurel forest dominates the middle section to the summit. Field survey 
showed the presence of Shorea maxima and Vatica umbonata (Dipterocarpaceae), Dacrydium elatum and Agathis borneensis (gymnosperms), many oak and highland myrtaceous species, Prunus arborea (Rosaceae), Vaccinium bancanum (Ericaceae) and a parasitic species of Balanophora fungosa. The summit zone of the study area showed the presence of typical montane fern such as Dipteris conjugata and thick cover bog mosses of Sphagnum of the forest floor. Latiff (2009) reported the domination of the family Lauraceae (42 species), Fagaceae (28 species), Orchidaceae (148 species) and Ericaceae at the summit zone. Adam and Maimon (2009) reported the existence of Nepenthes gracilis and Nepenthes sanguinea on this hill. Damahuri (2009) reported 172 species of mosses, thick carpet of Leucobryum, Ectropothecium and Rhodobryum on the wet forest floor hill. Haja (2009) reported 210 species of ferns and fern allies; highland species Cibotium barometz (Golden chicken fern), Cythea (tree fern), Dipteris conjugata (umbrella fern) and Belchnum orientale. Adam et al. (2010) studied the forest structures along Pine Trail in Fraser Hill and categorisation of forest by clustering method but the present study area is located outside FHRC. Thus, the current research will provide the base line data of the forest structures, particularly tree species composition at different elevations. The other objectives were classifying the forest along the slope into different cluster groups and to determine the effect of increasing elevation on forest structures by correlation analysis.

\section{Materials and Methods}

Classification of the forest at different altitudes on the western slope of FHRC, UKM in Raub District $03^{\circ} 43^{\prime}$ and $03^{\circ} 44^{\prime} \mathrm{N}$ and $101^{\circ} 43^{\prime}$ to $101^{\circ} 44^{\prime}$ E, Pahang State of Malaysia, was determined by Ward Linkage Method (WLM). Five plots, each measuring $10 \mathrm{~m} \times 100 \mathrm{~m}$ were set at 1000 , $1050,1100,1150$ and $1200 \mathrm{~m}$ altitudes and were denoted as P1, P2, P3, P4 and P5. In order to determine the frequency count (f) and calculation of relative frequency $\left(\mathrm{R}_{\mathrm{f}}\right)$ of every tree species, every plot was divided into 10 small compartments, each of them measuring $10 \mathrm{~m} \times 10 \mathrm{~m}$. For density count and basal area (BA) contribution, all trees with a DBH of $\geq 5 \mathrm{~cm}$ have been measured.

The BA, density, importance value, species diversity indices were determined by the formulae of Cintron and Novelli (1984).

Species diversity of the tree species was measured following the formulae of Ludwig and Reynolds (1988).

\section{Results and Discussion}

Clustering analysis has classified the forest along the western slope of FHRC between altitudes 1000 and $1200 \mathrm{~m}$ into four forest zones (FZ) (Fig. 1) and those are Dacrydium elatum Prunus arborea - Adinandra dumosa zone (FZ1P1, $1000 \mathrm{~m}$ ), Trigonobalanus verticillata Syzygium stapfianum - Syzygium subdecussatum Zone (FZ2P2, $1050 \mathrm{~m}$ ), Syzygium leptostemon Wikstroemia polyantha - Syzygium napiforme (FZ3P3P4, 1100-1150 m) and Syzygium filiforme Decaspermum parviflorum and Litsea machilifolia zone (FZ4P5, $1200 \mathrm{~m}$ ).

I. Dacrydium elatum - Prunus arborea - Adinandra dumosa Zone: The 25 forest attributes of FZ1P1 is summarised in Table 1. A total of 297 trees or estimated 2970/ha with a DBH of $\geq 5 \mathrm{~cm}$ was recorded. They were represented by 120 species belonging to 86 genus and 46 families. Guttiferae and Myrtaceae were the two most diverse families, each comprising of 8 species, followed very closely by Fagaceae with 7 species, Lauraceae and Rubiaceae with 6 species and Leguminosae with 5 species. Families with 4 species include Anacardiaceae, Annonaceae, Burseraceae, Euphorbiaceae, Rhizophoraceae and Sapindaceae. A total of 28 families contained between 1 and 2 species. However, in term of density Sapotaceae is the most dominant 
contributing $7.06 \%$ of the total trees recorded; other dominant families includes Myrtaceae and Moraceae, each contributing $5.05 \%$ of the total trees. The species diversity indices obtained in this FZ1P1 is shown in Table 1. The R, H' and E values obtained were 6.97, 4.55 and 0.94, respectively.

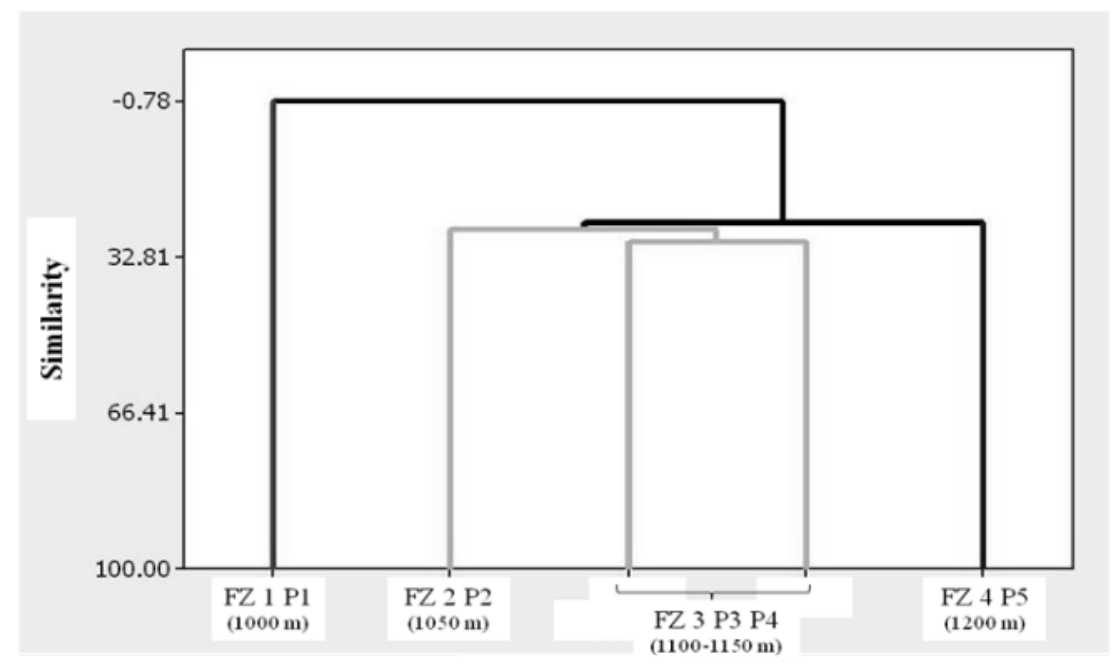

Forest zones

Fig. 1. Forest zones along the western slope of FHRC, Raub, Pahang.

Table 1. Forest attributes of four FZ at FHRC, UKM in Raub District, Pahang.

\begin{tabular}{|c|c|c|c|c|c|}
\hline \multicolumn{2}{|c|}{ Forest cluster attributes } & \multirow{2}{*}{$\begin{array}{c}\begin{array}{c}\text { FZ1P1 } \\
(1000 \mathrm{~m})\end{array} \\
0.1 \mathrm{ha}\end{array}$} & \multirow{2}{*}{$\begin{array}{c}\text { FZ2P2 } \\
(1050 \mathrm{~m})\end{array}$} & \multirow{2}{*}{$\begin{array}{c}\text { FZ3P3P4 } \\
(1100-1150 \mathrm{~m}) \\
0.2 \mathrm{ha}\end{array}$} & \multirow{2}{*}{$\begin{array}{r}\text { FZ4P5 } \\
(1200 \mathrm{~m} \\
0.1 \mathrm{ha}\end{array}$} \\
\hline 1 & Plot area & & & & \\
\hline 2 & Altitude (m) & 1000 & 1050 & $1100-1150$ & 1200 \\
\hline 3 & No. of trees & 297 & 168 & 455 & 198 \\
\hline 4 & Mean tree height $(\mathrm{m})$ & 12.5 & 12.4 & 12.95 & 8.6 \\
\hline 5 & Density/ha & 2970 & 1680 & 2750 & 1980 \\
\hline 6 & $\mathrm{DBH} \mathrm{cm}$ & 5352 & 3575 & 7037 & 2307 \\
\hline 7 & Mean DBH cm & 18.08 & 21.3 & 15.47 & 11.65 \\
\hline 8 & Number of species & 120 & 78 & 144 & 83 \\
\hline 9 & Number of family & 46 & 34 & 47 & 30 \\
\hline 10 & Number of genus & 89 & 58 & 95 & 54 \\
\hline 11 & Basal area $\mathrm{cm}^{2}$ & 122121 & 60263 & 127627 & 37144 \\
\hline 12 & Mean basal area $\mathrm{cm}^{2}$ & 417.92 & 358.71 & 280.50 & 187.60 \\
\hline 13 & $\mathrm{R}=\mathrm{S} / \sqrt{\mathrm{N}}$ & 6.97 & 6.01 & 6.75 & 5.88 \\
\hline 14 & $\mathrm{H}^{\prime}$ & 4.55 & 4.1 & 4.62 & 4.12 \\
\hline 15 & E & 0.94 & 0.94 & 0.93 & 0.93 \\
\hline 16 & No. and $\%$ of species with & 50 & 56 & 85 & 56 \\
\hline & $1-2$ trees & $63.96 \%$ & $71.68 \%$ & $58.69 \%$ & 67.46 \\
\hline 17 & $\begin{array}{l}\text { Species with highest } \\
\text { number of trees }\end{array}$ & $\begin{array}{l}\text { Adinandra dumosa } \\
\text { and Knema } \\
\text { kunstleri } 10\end{array}$ & $\begin{array}{l}\text { Syzygium } \\
\text { subdecussatum } 11\end{array}$ & $\begin{array}{l}\text { Syzygium } \\
\text { napiforme } 22\end{array}$ & $\begin{array}{l}\text { Syzygium } \\
\text { filiforme } 13\end{array}$ \\
\hline
\end{tabular}




\begin{tabular}{|c|c|c|c|c|c|}
\hline 18 & $\begin{array}{l}\text { Family with the highest no. } \\
\text { and } \% \text { of species }\end{array}$ & $\begin{array}{l}\text { Guttiferae } 8 \text { and } \\
6.66 \% \\
\text { Myrtaceae } 8 \text { and } \\
6.67 \%\end{array}$ & $\begin{array}{l}\text { Myrtaceae } 14 \\
17.95 \%\end{array}$ & $\begin{array}{l}\text { Myrtaceae } 16 \\
11.1 \%\end{array}$ & $\begin{array}{l}\text { Myrtaceae } 10 \\
12.05 \%\end{array}$ \\
\hline 19 & $\begin{array}{l}\text { Family with highest no. } \\
\text { and } \% \text { of trees }\end{array}$ & $\begin{array}{l}\text { Theaceae } \\
21 \text { and } 7.06 \%\end{array}$ & $\begin{array}{l}\text { Myrtaceae } \\
56 \text { and } 33.06 \%\end{array}$ & $\begin{array}{l}\text { Myrtaceae } 122 \\
26.84\end{array}$ & $\begin{array}{l}\text { Myrtaceae } \\
50 \text { and } 25.29 \%\end{array}$ \\
\hline 20 & $\begin{array}{l}\text { Family with highest } \mathrm{DBH} \\
\% \mathrm{DBH} \text { contribution }\end{array}$ & $\begin{array}{l}\text { Podocarpaceae } \\
918 \mathrm{~cm} \\
17.45 \%\end{array}$ & $\begin{array}{l}\text { Myrtaceae } \\
1423.33 \mathrm{~cm} \\
35.39 \%\end{array}$ & $\begin{array}{l}\text { Myrtaceae } \\
1841 \mathrm{~cm} \\
26.16 \%\end{array}$ & $\begin{array}{l}\text { Myrtaceae } \\
484.88 \mathrm{~cm} \\
20.85 \%\end{array}$ \\
\hline 21 & $\begin{array}{l}\text { Dominant species with } \\
\text { highest } I_{V}\end{array}$ & $\begin{array}{l}\text { Dacrydium elatum } \\
19.71 \%\end{array}$ & $\begin{array}{l}\text { Trigonobalanus } \\
\text { verticillata } 13.97 \%\end{array}$ & $\begin{array}{l}\text { Syzygium } \\
\text { leptostemon } \\
11.96 \%\end{array}$ & $\begin{array}{l}\text { Syzygium filiforme } \\
13.02 \%\end{array}$ \\
\hline 22 & $\begin{array}{l}\text { Co-dominant species with } \\
\text { 2nd highest } I_{v}\end{array}$ & $\begin{array}{l}\text { Prunus arborea } \\
15.36 \%\end{array}$ & $\begin{array}{l}\text { Syzygium } \\
\text { stapfianum } 13.13 \%\end{array}$ & $\begin{array}{l}\text { Wikstroemia } \\
\text { polyantha } 11.33\end{array}$ & $\begin{array}{l}\text { Decaspermum } \\
\text { parviflorum } 12.78 \%\end{array}$ \\
\hline 23 & $\begin{array}{l}\text { Co-dominant species with } \\
\text { 3rd highest } I_{v}\end{array}$ & $\begin{array}{l}\text { Adinandra dumosa } \\
7.73 \%\end{array}$ & $\begin{array}{l}\text { Syzygium subdecu- } \\
\text { ssatum } 12.68 \%\end{array}$ & $\begin{array}{l}\text { Syzygium napi- } \\
\text { forme } 10.24 \%\end{array}$ & $\begin{array}{l}\text { Litsea machilifolia } \\
11.63 \%\end{array}$ \\
\hline 24 & $\begin{array}{l}\text { Dominant family with } \\
\text { highest } I_{V}\end{array}$ & $\begin{array}{l}\text { Podocarpaceae } \\
19.71 \%\end{array}$ & $\begin{array}{l}\text { Myrtaceae } \\
79.49 \%\end{array}$ & $\begin{array}{l}\text { Myrtaceae } \\
72.01 \%\end{array}$ & $\begin{array}{l}\text { Myrtaceae } \\
62.90 \%\end{array}$ \\
\hline 25 & $\begin{array}{l}\text { Co-dominant family } \\
\text { with } 2 \text { nd highest } I_{v}\end{array}$ & $\begin{array}{l}\text { Guttiferae } \\
18.46 \%\end{array}$ & $\begin{array}{l}\text { Fagaceae } \\
51.86 \%\end{array}$ & $\begin{array}{l}\text { Fagaceae } \\
20.91 \%\end{array}$ & $\begin{array}{l}\text { Lauraceae } \\
36.94 \%\end{array}$ \\
\hline 26 & $\begin{array}{l}\text { Co-dominant family } \\
\text { with 3rd highest } I_{v}\end{array}$ & $\begin{array}{l}\text { Rosaceae } \\
17.26 \%\end{array}$ & $\begin{array}{l}\text { Thymelaeaceae } \\
21.18 \%\end{array}$ & $\begin{array}{l}\text { Guttiferae } \\
20.62 \%\end{array}$ & $\begin{array}{l}\text { Fagaceae } \\
25.93 \%\end{array}$ \\
\hline 27 & $\begin{array}{l}\text { Species with biggest } \\
\text { DBH }\end{array}$ & $\begin{array}{l}\text { Dacrydium } \\
\text { elatum } \\
135 \mathrm{~cm}\end{array}$ & $\begin{array}{l}\text { Trigonobalanus } \\
\text { verticillata } \\
98.5 \mathrm{~cm}\end{array}$ & $\begin{array}{l}\text { Syzygium } \\
\text { leptostemon } \\
100.5 \mathrm{~cm}\end{array}$ & $\begin{array}{l}\text { Dacrydium elatum } \\
43 \mathrm{~cm}\end{array}$ \\
\hline
\end{tabular}

It is revealed that $73.1 \%$ of the trees inventoried fall into two small DBHC that is $32.3 \%$ fall into DBHC1 and $40.8 \%$ fall into DBHC2 (Table 2). The table also indicated that only $0.68 \%$ or 2 of the total 297 trees inventoried belonged to DBHC7. These trees were represented by Dacrydium elatum (Podocarpaceae) with a DBH of $135 \mathrm{~cm}$ and Prunus arborea (Rosaceae) with a DBH of $126 \mathrm{~cm}$. The total DBH and BA of all trees recorded in this FA were $5352 \mathrm{~cm}$ and $122121 \mathrm{~cm}^{2}$, giving us the mean DBH and mean BA area of $18.03 \mathrm{~cm}$ and $417.92 \mathrm{~cm}^{2}$, respectively.

Table 2. Distribution of trees between seven DBHC in four FZ at FHRC, UKM in Raub, Pahang.

\begin{tabular}{|c|c|c|c|c|c|c|c|c|}
\hline \multirow[t]{2}{*}{ DBH (class ) } & \multicolumn{2}{|c|}{ FZ1P1 } & \multicolumn{2}{|c|}{ FZ2P2 } & \multicolumn{2}{|c|}{ FZ3P3P4 } & \multicolumn{2}{|c|}{ FZ4P5 } \\
\hline & No. & $\%$ of trees & No. & $\%$ of trees & No. & $\%$ of trees & No. & $\%$ of trees \\
\hline $5-10(1)$ & 95 & 32.3 & 70 & 42.7 & 179 & 39.02 & 86 & 43.86 \\
\hline $10.1-20(2)$ & 120 & 40.8 & 51 & 31.11 & 175 & 38.15 & 87 & 44.31 \\
\hline $20.1-30(3)$ & 37 & 12.58 & 24 & 14.64 & 70 & 15.26 & 12 & 6.12 \\
\hline $30.1-40(4)$ & 29 & 9.86 & 11 & 6.71 & 20 & 4.36 & 10 & 5.10 \\
\hline $40.1-50(5)$ & 9 & 3.06 & 2 & 1.22 & 7 & 1.53 & 2 & 1.02 \\
\hline $50.1-100(6)$ & 4 & 1.36 & 7 & 4.27 & 7 & 1.53 & 0 & 0 \\
\hline $100.1-150(7)$ & 2 & 0.68 & 0 & 0 & 1 & 0.22 & 0 & 0 \\
\hline Total & 297 & & 165 & & 459 & & 197 & \\
\hline
\end{tabular}

The importance value of 8 species, exclusive of 112 species with $I_{v}$ from 0.77 to $5.27 \%$ in FZ1P1 (Table 4). The dominant species possessing the highest $I_{v}$ was Dacrydium elatum (Podocarpaceae) with $\mathrm{I}_{\mathrm{v}}$ of $19.71 \%$. The first and second co-dominant species having the second and third highest $\mathrm{I}_{\mathrm{v}}$ were Prunus arborea (Rosaceae) and Adinandra dumosa (Theaceae) with $\mathrm{I}_{\mathrm{v}}$ of $15.36 \%$ and $7.73 \%$, respectively. Two other species with $I_{v}$ greater than $7 \%$ were Ixonanthes 
icosandra and Cratoxylum arborescens. In term of family, Podocarpaceae was the most dominant family having the $\mathrm{I}_{\mathrm{v}}$ of $19.71 \%$ (Table 1). The first and second co-dominant families were Guttiferae and Rosaceae with $\mathrm{I}_{\mathrm{v}}$ of $18.46 \%$ and $17.26 \%$, respectively. The Table 3 indicated that $61.42 \%$ of the total 120 species recorded fall into $\mathrm{I}_{v} \mathrm{C}_{2}$ and $31.54 \%$ fall into $\mathrm{I}_{\mathrm{v}} \mathrm{C} 1$. The percentage of the species belonged to $\mathrm{I}_{\mathrm{v}} \mathrm{C} 5$ is very small, $1.66 \%$ or represented by 2 species; these species were the dominant and first co-dominant species having the highest and second highest $\mathrm{I}_{\mathrm{v}}$ (Table 4). The second co-dominant species, Adinandra dumosa was shown to fall into $\mathrm{I}_{\mathrm{v}} \mathrm{C} 3$.

Table 3. Distribution of species between five $I_{v} C$ in four FZ at FHRC, UKM in Raub, Pahang.

\begin{tabular}{|c|c|c|c|c|c|c|c|c|}
\hline \multirow[t]{2}{*}{$\mathrm{I}_{\mathrm{V}}$ class } & \multicolumn{2}{|c|}{ FZ1P1 } & \multicolumn{2}{|c|}{ FZ2P2 } & \multicolumn{2}{|c|}{ FZ3P3P4 } & \multicolumn{2}{|r|}{ FZ4P5 } \\
\hline & No. & $\%$ of trees & No. & $\%$ of trees & No. & $\%$ of trees & No. & $\%$ of trees \\
\hline $\mathrm{I}_{\mathrm{V}} \mathrm{C} 1: \leq 1$ & 35 & 31.54 & 0 & 0 & 43 & 29.86 & 0 & 0 \\
\hline $\mathrm{I}_{\mathrm{V}} \mathrm{C} 2: 1.1-5$ & 74 & 61.42 & 60 & 77.68 & 92 & 63.89 & 66 & 79.2 \\
\hline $\mathrm{I}_{\mathrm{V}} \mathrm{C} 3: 5.1-10$ & 8 & 7.47 & 14 & 17.92 & 4 & 2.78 & 13 & 15.7 \\
\hline $\mathrm{I}_{\mathrm{V}} \mathrm{C} 4: 10.1-15$ & 0 & 0 & 4 & 5.12 & 5 & 3.47 & 4 & 4.9 \\
\hline $\mathrm{I}_{\mathrm{V}} \mathrm{C} 5: 15.1-20$ & 2 & 1.66 & 0 & 0 & 0 & 0 & 0 & 0 \\
\hline Total & 120 & & 78 & & 144 & & 83 & \\
\hline
\end{tabular}

Table 4. Percentage of $R_{f}, R_{d}, R_{D}$ and $I_{v}$ of all tree species with dbh of $\geq 5 \mathrm{~cm}$ in FZ1P1 at $1000 \mathrm{~m}$ in FHRC, UKM in Raub, Pahang*.

\begin{tabular}{lllcccc}
\hline & Species & Family & $\mathrm{R}_{\mathrm{f}}$ & $\mathrm{R}_{\mathrm{d}}$ & $\mathrm{R}_{\mathrm{D}}$ & $\mathrm{I}_{\mathrm{v}}$ \\
\hline 1 & Dacrydium elatum & Podocarpaceae & 1.25 & 1.01 & 17.45 & 19.71 \\
2 & Prunus arborea & Rosaceae & 2.08 & 2.36 & 10.92 & 15.36 \\
3 & Adinandra dumosa & Theaceae & 1.67 & 3.70 & 2.36 & 7.73 \\
4 & Ixonanthes icosandra & Ixonanthaceae & 2.92 & 3.70 & 1.03 & 7.65 \\
5 & Cratoxylum arborescens & Guttiferae & 2.08 & 2.02 & 2.95 & 7.06 \\
6 & Lithocarpus lucidus & Fagaceae & 1.25 & 1.68 & 2.54 & 5.48 \\
7 & Aglaia forbesii & Meliaceae & 2.08 & 2.69 & 0.67 & 5.45 \\
8 & Artocarpus integer & Moraceae & 1.67 & 2.02 & 1.65 & 5.34 \\
\hline
\end{tabular}

*112 species with $\mathrm{I}_{\mathrm{v}}$ between 0.77 and $5.27 \%$ were excluded from the table.

II. Trigonobalanus verticillata - Syzygium stapfianum - Syzygium subdecussatum Zone: A total of 168 trees or estimated 1680/ha with a DBH of $\geq 5 \mathrm{~cm}$ was recorded. They were represented by 78 species belonging to 58 genus and 34 families. Myrtaceae were the most diverse family containing 14 species, followed by Fagaceae with 7 species and Guttiferae with 6 species. 18 families were found to possess 1 species each, 5 and 7 families respectively contained 2 and 3 species. However, in term of density, Myrtaceae is the most dominant contributing $33.06 \%$ (56) of the total trees recorded; other dominant families contributing between 7.08 and $7.67 \%$ of the total trees includes Thymelaeaceae, Fagaceae and Guttiferae. Families contributing greater than $2 \%$ but less than $5 \%$ include Burseraceae, Ebenaceae, Euphorbiaceae, Meliaceae and Thymelaeaceae. A total of 20 families were found to contribute less than $2 \%$ of the total trees recorded each. The species diversity indices obtained in this FZ2P2 is shown in Table 1. The R, H and $\mathrm{E}$ values obtained were $6.01,4.1$ and 0.94 , respectively.

This study also revealed that $88.45 \%$ of the trees inventoried fall into two small DBHC that is $42.7 \%$ fall into DBHC1, $31.11 \%$ fall into DBHC2 and 14.64\% fall into DBHC3 (Table 2). The table also indicated that $4.27 \%$ ( 7 trees) belonged to big DBHC that is DBHC6. These trees were represented by Trigonobalanus verticillata $(\mathrm{dbh}=98.5 \mathrm{~cm})$, Vatica umbonata $(\mathrm{dbh}=80 \mathrm{~cm})$, Lithocarpus wrayi $(\mathrm{dbh}=66 \mathrm{~cm})$, Quercus gaharuensis $(\mathrm{dbh}=60 \mathrm{~cm})$, Quercus gemellifolia $(\mathrm{dbh}$ 
$=54 \mathrm{~cm}$ ), The total DBH and BA of all trees recorded in this FA2 were $2717 \mathrm{~cm}$ and 59862.22 $\mathrm{cm}^{2}$, giving us the mean DBH and mean BA area of $16.45 \mathrm{~cm}$ and $362.80 \mathrm{~cm}^{2}$, respectively.

The importance values of 18 species, excluding 60 species with $\mathrm{I}_{\mathrm{v}}$ from 1.43 to $4.89 \%$ in FZ2P2 is tabulated in Table 5. The dominant species having the highest $\mathrm{I}_{\mathrm{v}}$ was Trigonobalanus verticillata (Fagaceae) with $\mathrm{I}_{\mathrm{v}}$ of $13.97 \%$. The first and second co-dominant species having the second and third highest $\mathrm{I}_{\mathrm{v}}$ were Syzygium stapfianum (Myrtaceae) and Syzygium subdecussatum with $\mathrm{I}_{\mathrm{v}}$ of 13.13 and $12.68 \%$. Species with $\mathrm{I}_{\mathrm{v}}$ greater than $8 \%$ includes Decaspermum parviflorum, Quercus gemelliflora, Paranephelium, Vatica umbonata and Wikstroemia polyantha. In term of family, Myrtaceae was the most dominant family having the $I_{v}$ of $79.49 \%$ (Table 1). The first and second co-dominant families were Fagaceae and Thymelaeaceae with $\mathrm{I}_{\mathrm{v}}$ of 51.86 and $21.18 \%$. Analysis on the distribution of species in different $\mathrm{I}_{\mathrm{v}} \mathrm{C}$ was shown in Table 3 above. The table indicated that $76.8 \%$ of the total 78 species recorded fall into $\mathrm{I}_{v} \mathrm{C} 2$ and $17.92 \%$ fall into $\mathrm{I}_{\mathrm{v}} \mathrm{C} 3$. The percentage of the species belonged to $\mathrm{I}_{\mathrm{v}} \mathrm{C} 4$ is $5.12 \%$ or represented by 4 species; these species belong to the 4 largest $I_{v}$ recorded that is Trigonobalanus verticillata, Syzygium stapfianum, Syzygium subdecussatum and Wikstroemia polyantha (Table 5).

Table 5. Percentage of $R_{f}, R_{d}, R_{D}$ and $I_{v}$ of all tree species with dbh of $\geq 5 \mathrm{~cm}$ in FZ2P2 at $1050 \mathrm{~m}$ in FHRC, UKM in Raub, Pahang*.

\begin{tabular}{rllcccc}
\hline & Species & Family & $\mathrm{RD}$ & $\mathrm{R}_{\mathrm{d}}$ & $\mathrm{R}_{\mathrm{f}}$ & $\mathrm{I}_{\mathrm{v}}$ \\
\hline 1 & Trigonobalanus verticillata & Fagaceae & 12.58 & 0.59 & 0.8 & 13.97 \\
2 & Syzygium stapfianum & Myrtaceae & 3.42 & 6.51 & 3.2 & 13.13 \\
3 & Syzygium subdecussatum & Myrtaceae & 5.35 & 4.13 & 3.2 & 12.68 \\
4 & Wikstroemia polyantha & Thymelaeaceae & 6.02 & 3.54 & 2.4 & 11.96 \\
5 & Vatica umbonata & Dipterocarpaceae & 8.3 & 0.59 & 0.8 & 9.69 \\
6 & Paranephelium & Sapindaceae & 2.53 & 2.95 & 3.2 & 8.68 \\
7 & Quercus gemelliflora & Fagaceae & 5.17 & 1.77 & 1.6 & 8.54 \\
8 & Decaspermum parviflorum & Myrtaceae & 0.91 & 3.54 & 4 & 8.45 \\
9 & Tristaniopsis merguensis & Myrtaceae & 3.16 & 2.36 & 2.4 & 7.92 \\
10 & Quercus gaharuensis & Fagaceae & 5.04 & 1.18 & 1.6 & 7.82 \\
11 & Lithocarpus wrayi & Fagaceae & 5.65 & 0.59 & 0.8 & 7.04 \\
12 & Syzygium claviflorum & Myrtaceae & 1.9 & 3.54 & 1.6 & 7.04 \\
13 & Lithocarpus scortechnii & Fagaceae & 3.49 & 1.77 & 1.6 & 6.86 \\
14 & Calophyllum wallichianum & Guttiferae & 1.61 & 3.54 & 1.6 & 6.75 \\
15 & Aquilaria malaccensis & Thymelaeaceae & 1.35 & 2.95 & 2.4 & 6.7 \\
16 & Syzygium curtisii & Myrtaceae & 2.31 & 2.36 & 1.6 & 6.27 \\
17 & Melia & Meliaceae & 0.61 & 2.36 & 3.2 & 6.17 \\
18 & Syzygium garcinifolium & Myrtaceae & 0.94 & 2.36 & 2.4 & 5.7 \\
\hline
\end{tabular}

*60 species with $\mathrm{I}_{\mathrm{v}}$ between 1.43 and $4.89 \%$ were excluded from the table.

III. Syzygium leptostemon, Wikstroemia poyantha - Syzygium napifome Zone: A total of 455 trees or estimated 2750/ha with a DBH of $\geq 5 \mathrm{~cm}$ was recorded. They were represented by 144 species belonging to 95 genus and 47 families. Myrtaceae were the most diverse family containing 16 species, followed by Guttiferae with 12 species and Fagaceae with 11 species. Families with 6-7 species include Sapotaceae, Lauraceae and Theaceae. 21 of the total 47 families 
recorded were found to contain 1 species each, 7, 5 and 5 families, respectively contained 2, 3 and 4 species. However, in term of density, Myrtaceae is the most dominant contributing $26.84 \%$ of the total trees recorded; other dominant families contributing between 5.5 and $10.54 \%$ of the total trees includes Rutaceae (10.54\%), Guttiferae (7.28\%), Fagaceae (5.94\%) and Theaceae (5.5\%). Families contributing between 3 and $4.4 \%$ include Flacourtiaceae, Sapotaceae, Lauraceae and Thymelaeaceae. A total of 23 families were found to contribute less than $1 \%$ of the total trees recorded each. The species diversity indices obtained in this FZ3 is shown in Table 1. The R, H' and $E$ values obtained were $6.75,4.62$ and 0.93 , respectively.

This study also showed that $92.43 \%$ of the trees inventoried fall into two small DBHC that is $39.02 \%$ fall into DBHC1, 38.15\% fall into DBHC2 and 15.26\% fall into DBHC3 (Table 2). The table also indicated that only $7.64 \%$ of tree inventoried belonged to DBHC4-7. Of these $1.75 \%$ (8 trees) were belong to DBHC6 and DBHC7. These trees were represented by Syzygium leptostemon (Myrtaceae) with a DBH of $100.5 \mathrm{~cm}$, Aquilaria malaccensis with DBH of $70 \mathrm{~cm}$, Wikstroemia polyantha with DBH of $65 \mathrm{~cm}$ and $50 \mathrm{~cm}$, Santiria rubiginosa (Burseraceae) with a DBH of 64.5 $\mathrm{cm}$, Perrottetia alpestris (Celastraceae) with DBH of $57.5 \mathrm{~cm}$, Hydnocarpus wrayi (Lauraceae) with DBH of $57 \mathrm{~cm}$ and Lindera pipericarpa (Lauraceae) with DBH of $53 \mathrm{~cm}$. The total DBH and BA of all trees recorded in this FA were $5352 \mathrm{~cm}$ and $122121 \mathrm{~cm}^{2}$, giving us the mean DBH and mean BA area of $18.03 \mathrm{~cm}$ and $417.92 \mathrm{~cm} 2$, respectively.

The importance values of species, excluding 136 species with $I_{v}$ from 0.57 to $4.88 \%$ in FZ3P3P4 (Table 6). The dominant species having the highest $I_{v}$ was Syzygium leptostemon (Myrtaceae) with $\mathrm{I}_{\mathrm{v}}$ of $11.96 \%$. The first and second co-dominant species having the second and third highest $\mathrm{I}_{\mathrm{v}}$ were Wikstroemia polyantha (Thymelaeaceae) and Syzygium napiforme (Myrtaceae) with $I_{v}$ of 11.33 and $10.24 \%$. Species with $I_{v}$ greater than $10 \%$ is Decaspermum parviflorum. In term of family, Myrtaceae was the most dominant family having the $\mathrm{I}_{\mathrm{v}}$ of $72.01 \%$ (Table 1). The first and second co-dominant families were Fagaceae and Guttiferae with $I_{v}$ of 20.91 and $20.62 \%$. Analysis on the distribution of species in different $I_{v}$ class was shown in Table 3. The table indicated that $63.89 \%$ of the total 144 species recorded fall into $\mathrm{I}_{\mathrm{v}} \mathrm{C} 2$ and $29.86 \%$ fall into $\mathrm{I}_{\mathrm{v}} \mathrm{C} 1$. The percentage of the species belonged to $\mathrm{I}_{v} \mathrm{C} 3$ is 2.78 and $3.47 \%$ fall into $\mathrm{I}_{\mathrm{v}} \mathrm{C} 4$.

Table 6. Percentage of $R_{f}, R_{d}, R_{D}$ and $I_{v}$ of all tree species with a DBH of $\geq 5 \mathrm{~cm}$ in FZ3P3P4 at $1100-1150 \mathrm{~m}$ in FHRC, UKM in Raub District of Pahang*.

\begin{tabular}{lllcccc}
\hline & Species & Family & $\mathrm{R}_{\mathrm{d}}$ & $\mathrm{R}_{\mathrm{f}}$ & $\mathrm{R}_{\mathrm{D}}$ & $\mathrm{I}_{\mathrm{v}}$ \\
\hline 1 & Syzygium leptostemon & Myrtaceae & 2.42 & 1.62 & 7.92 & 11.96 \\
2 & Wikstroemia polyantha & Thymelaeaceae & 2.2 & 1.89 & 7.24 & 11.33 \\
3 & Syzygium napiforme & Myrtaceae & 4.84 & 2.43 & 2.97 & 10.24 \\
4 & Decaspermum parviflorum & Myrtaceae & 3.74 & 2.97 & 3.44 & 10.15 \\
5 & Aquilaria malaccensis & Thymelaeaceae & 1.54 & 1.08 & 4.14 & 6.76 \\
6 & Syzygium cerinum & Myrtaceae & 2.42 & 1.89 & 2.15 & 6.46 \\
7 & Prunus arborea & Rosaceae & 1.76 & 2.16 & 2.28 & 6.2 \\
8 & Gordonia taipengensis & Theaceae & 1.98 & 2.43 & 0.85 & 5.26 \\
\hline
\end{tabular}

*136 species with $\mathrm{I}_{\mathrm{v}}$ between $0.57-4.88 \%$ were excluded from the table.

IV. Syzygium filiforme - Decaspermum parviflorum - Litsea machilifolia Zone: A total of 198 trees or estimated $1980 \mathrm{ha}^{-1}$ with a DBH of $\geq 5 \mathrm{~cm}$ was recorded. They were represented by 83 species belonging to 54 genus and 30 families. Myrtaceae were the most diverse family containing 10 species, followed by Guttiferae and Lauraceae with 8 species each and Fagaceae and Theaceae with 7 species each. Families with 3 species include Burseraceae, Elaeocarpaceae, 
Euphorbiaceae and Rubiaceae. 13 and 9 of the total 47 families recorded were found to contain 1 and 2 species each, respectively. However, in term of density, Myrtaceae is the most dominant contributing $25.29 \%$ of the total trees recorded; the first and second co-dominant families contribution 10.63 and $7.60 \%$ of the total trees were Lauraceae and Guttiferae; Theaceae too contribute $7.10 \%$ of the total trees; families contributing between 3 and $7 \%$ of the total trees include Fagaceae (6.08\%), Flacourtiaceae (4.57\%), Melastomataceae (4.05\%) and Polygalaceae (3.54\%), 8 families were found to contribute less than $1 \%$ and 15 families contributing $1-3 \%$ of the total trees recorded each. The species diversity indices obtained in FA4 is shown in Table 1. The R, H' and E values obtained were 5.88, 4.12 and 0.93 , respectively.

This study showed that $88.17 \%$ of the trees inventoried fall into two small DBHC that is $44.31 \%$ fall into DBHC2 and $43.86 \%$ fall into DBHC1 (Table 2). The table also showed that 6.12 and $5.10 \%$ of the trees inventoried belonged to DBHC3 and DBHC4. It was also found that $1.02 \%$ of these trees fall into DBHC5; these trees were represented by Dacrydium elatum (Podocarpaceae) with a DBH of $43 \mathrm{~cm}$, Aquilaria malaccensis with DBH of $70 \mathrm{~cm}$, Wikstroemia polyantha with DBH of $65 \mathrm{~cm}$ and $50 \mathrm{~cm}$ and Litsea machilifolia (Lauraceae) with a DBH of 40 $\mathrm{cm}$, The total DBH and BA of all trees recorded in FA4 were $2307 \mathrm{~cm}$ and $37145.83 \mathrm{~cm}^{2}$, giving us the mean DBH and mean BA area of $11.65 \mathrm{~cm}$ and $187.60 \mathrm{~cm}^{2}$, respectively.

The importance values of 17 species, excluding 66 species with $I_{v}$ from 1.25 to $4.67 \%$ in FZ4P5 is given in Table 7. The dominant species having the highest $\mathrm{I}_{\mathrm{v}}$ was Syzygium filiforme (Myrtaceae) with $\mathrm{I}_{\mathrm{v}}$ of $13.02 \%$. The first and second co-dominant species having the second and third highest $I_{v}$ were Decaspermum parviflorum (Myrtaceae) and Litsea machilifolia (Lauraceae)

Table 7. Percentage of $R_{f}, R_{d}, R_{D}$ and $I_{v}$ of all tree species with a DBH of $\geq 5 \mathrm{~cm}$ in FZ4P5 at $1200 \mathrm{~m}$ in FHRC, UKM in Raub, Pahang*.

\begin{tabular}{lllcccc}
\hline & Species & Family & $\mathrm{R}_{\mathrm{f}}$ & $\mathrm{Rd}$ & $\mathrm{R}_{\mathrm{D}}$ & $\mathrm{I}_{\mathrm{v}}$ \\
\hline 1 & Syzygium filiforme & Myrtaceae & 2.68 & 6.57 & 3.76 & 13.02 \\
2 & Decaspermum parviflorum & Myrtaceae & 4.7 & 5.05 & 3.03 & 12.78 \\
3 & Litsea machilifolia & Lauraceae & 2.68 & 3.03 & 5.92 & 11.63 \\
4 & Memecylon megacarpum & Melastomataceae & 2.68 & 2.53 & 5.05 & 10.26 \\
5 & Xanthophyllum affine & Polygalaceae & 2.68 & 3.03 & 3.99 & 9.71 \\
6 & Syzygium garcinifolium & Myrtaceae & 2.68 & 3.03 & 2.45 & 8.16 \\
7 & Lindera lucida & Lauraceae & 2.68 & 2.53 & 2.51 & 7.72 \\
8 & Lithocarpus elegans & Fagaceae & 2.01 & 1.52 & 3.75 & 7.28 \\
9 & Melia sp. & Meliaceae & 2.68 & 2.53 & 1.54 & 6.75 \\
10 & Ryparosa wallichii & Flacourtiaceae & 2.68 & 3.03 & 0.78 & 6.49 \\
11 & Aglaia malaccensis & Meliaceae & 2.68 & 2.02 & 1.76 & 6.47 \\
12 & Syzygium napiforme & Myrtaceae & 1.34 & 3.54 & 1.43 & 6.3 \\
13 & Syzygium chloranthum & Myrtaceae & 0.67 & 1.52 & 3.86 & 6.05 \\
14 & Tristaniopsis merguensis & Myrtaceae & 1.34 & 1.52 & 2.93 & 5.79 \\
15 & Quercus elmeri & Fagaceae & 1.34 & 1.01 & 2.88 & 5.23 \\
16 & Ixonanthes icosandra & Ixonanthaceae & 2.01 & 2.53 & 0.59 & 5.13 \\
17 & Dacrydium elatum & Coniferae & 0.67 & 0.51 & 3.86 & 5.03 \\
\hline
\end{tabular}

*66 species with Iv between 1.25 and $4.67 \%$ were excluded from the table. 
with $\mathrm{I}_{\mathrm{v}}$ of 12.78 and $11.64 \%$. Species with $\mathrm{I}_{\mathrm{v}}$ greater than $8 \%$ includes Memecylon megacarpum, Xanthophyllum affine and Syzygium garcinifolium, In term of family, Myrtaceae was the most dominant family having the $\mathrm{I}_{\mathrm{v}}$ of $72.01 \%$ (Table 1 ). The first and second co-dominant families were Lauraceae and Fagaceae with $I_{v}$ of 36.94 and $25.93 \%$. Two other notable families with $I_{v}$ of 24.07 and $18.67 \%$ were Theaceae and Guttiferae.

Analysis on the distribution of species in different $I_{v}$ class was shown in Table 3. The table indicated that $79.2 \%$ of the total 83 species recorded fall into $\mathrm{I}_{v} \mathrm{C} 2$ and $15.7 \%$ fall into $\mathrm{I}_{\mathrm{v}} \mathrm{C} 3$. The percentage of the species belonged to $\mathrm{I}_{\mathrm{v}} \mathrm{C} 4$ is $4.9 \%$.

Influence of altitude on forest structures: Previous researchers have demonstrated a distinctive influence of altitude on changes in the forest structures on the vegetation of tropical rain forest (Adam et al. 2010, Adam and Enning 1996, Ohsawa et al. 1985, Kochummen 1982).

In this study, correlation analysis has been carried out in order to establish the effect of elevation on changes in forest structures of the study area. The analysis on 15 forest structures has carried out to determine the strength of their strength of correlation with increasing altitude. This analysis has obtained the negative r-values from 0.29 to 0.99 and a positive r-value of 0.96 (Table 8). The negative value showed a decrease in the value of forest structure with increasing altitude and vice versa. The $\mathrm{r}$-value of greater than $70 \%$ obtained from this study indicated a strong correlation with increasing altitude and vice versa. Table 8 showed a strong negative correlation

Table 8. Correlation analysis of 16 forests attributes in descending order of important of four FZ along the western slope of FHRC, UKM in Raub District, Pahang.

\begin{tabular}{lllllll}
\hline & Forest attributes & FZ1P1 & FZ2P2 & FZ3P3P4 & FZ4P5 & Correlation r \\
\hline 1 & Mean BA $\left(\mathrm{cm}^{2}\right)$ & 417.92 & 358.71 & 280.50 & 187.6 & -0.99 \\
2 & Biggest DBH of tree $(\mathrm{cm})$ & 135 & 98.5 & 100.5 & 43 & -0.97 \\
3 & \% of trees with DBH $>30 \mathrm{~cm}$ & 14.96 & 13.26 & 7.42 & 6.16 & -096 \\
4 & E & 0.94 & 0.94 & 0.93 & 0.93 & -0.85 \\
5 & Mean DBH cm & 18.08 & 21.3 & 15.47 & 11.65 & -0.84 \\
6 & Mean tree height $(\mathrm{m})$ & 12.5 & 12.4 & 12.95 & 8.6 & -0.83 \\
7 & $\mathrm{I}_{\mathrm{v}}$ of Dominant species $(\%)$ & 19.71 & 13.97 & 11.96 & 13.02 & -0.72 \\
8 & $\mathrm{R}=\mathrm{S} / \sqrt{\mathrm{N}}$ & 6.97 & 6.01 & 6.75 & 5.88 & -0.65 \\
9 & Number of family & 46 & 34 & 47 & 30 & -0.61 \\
10 & $\mathrm{I}_{\mathrm{v}}$ of $1^{\text {st }}$ co-dominant species $(\%)$ & 15.36 & 13.13 & 11.33 & 12.78 & -0.60 \\
11 & Number of genus & 89 & 58 & 95 & 54 & -0.51 \\
12 & $\mathrm{H}^{\prime}$ & 4.55 & 4.1 & 4.62 & 4.12 & -0.43 \\
13 & Estimated Density/ha & 2970 & 1680 & 2750 & 1980 & -0.42 \\
14 & $\mathrm{I}_{\mathrm{v}}$ of 2 ${ }^{\text {nd }}$ co-dominant species $(\%)$ & 7.73 & 12.68 & 11.29 & 11.63 & -0.42 \\
15 & Number of species & 120 & 78 & 144 & 83 & -0.29 \\
16 & $\%$ of trees with DBH 5 $20 \mathrm{~cm}$ & 14.96 & 13.26 & 7.42 & 6.12 & 0.96 \\
\hline
\end{tabular}

of first 7 attributes as listed with r-values from 0.72 to 0.99 ; the next 9 attributes established a weak negative correlation, with r-values from 0.29 to 0.62 . The results of this study conform to the finding of previous reports. On the other hand, percentage of small size trees with DBH of 5 - 20 $\mathrm{cm}$ with r-value of 0.96 , decrease significantly with increasing altitude. This study also showed that number of trees with $\mathrm{DBH}>50 \mathrm{~cm}$ is not recorded at $1200 \mathrm{~m}$ but 7,7 and 4 trees respectively with DBH $>50 \mathrm{~cm}$ are recorded at 1000,1050 and $1100-1150 \mathrm{~m}$, respectively. Similar results have also been obtained by other past researchers (Adam et al. 2007, Adam and Enning 1996). 
Previous studies showed that forest zonation is related with altitude in tropical mountains (Ohsawa et al.1985, Adam and Enning 1996). Lowland rain forest having three canopy layers with distinct emergent is found at the foot of the mountain, changing into two canopies without emergent layer at mid-elevation and conspicuously change into gnarled forest made up of one tree layer toward the peak of the mountain. The changing structures of this forest is very obvious along the ridge in very high ( $(9$ mountain such as Mt. Kinabalu (4101 m) and Mt Trusmadi (2642 m) in Sabah, Mt. Murud (2424 m) and Mt. Mulu in Sarawak and Mt. Brinchang in Peninsular Malaysia. Factors such as temperature, relative humidity, rainfall, wind velocity and light intensity do not vary or change uniformly with increasing altitude and the rate of change of climate with altitude differs from one area to the other depending on topography and other factors (Adam and Enning 1996). This variation thus determine the actual limit of vegetation on different mountain or hills of the tropic and on other section of the same mountain range. On coastal hill and isolated peak and ridges, the limit of vegetation are lower than those of inland mountain range (Adam and Enning 1996).

Clustering analysis using WLM has classified the forest of the study area into four forest zones. These forest zones are correlated with altitudes; FZ1 is found at $1000 \mathrm{~m}, \mathrm{FZ2}$ at $1050 \mathrm{~m}$, FZ3 at $1100-1150 \mathrm{~m}$ and FZ4 at 1200. Similar results were demonstrated by other researchers (Adam \& Enning 1996; Ohsawa et al. 1985). Adam and Enning (1996) divided the tropical rain forest at Danum Valley, Sabah State of Malaysia into FZ1 which occurs at $150-250 \mathrm{~m}, \mathrm{FZ2}$ at $350-500 \mathrm{~m}, \mathrm{FZ3}$ at $600-700 \mathrm{~m}, \mathrm{FZ4}$ at $820 \mathrm{~m}$. Ohsawa et al. (1985) found out that the forest at Mount Kerinci, Sumatra into four zones that is FZ at $1750-2100$ m, FZ2 at $2100-2400$ m, FZ3 at $2400-2900 \mathrm{~m}$ and FZ4 at $2900-3200 \mathrm{~m}$.

These forest zones are characterised by the dominant species and two co-dominant species having the highest, second and third highest $I_{v}$, respectively. The combination of these three species differs between FZ. In FZ1 these species were represented by Dacrydium elatum, Prunus arborea and Adinandra dumosa, FZ2 were represented by Trigonobalanus verticillata, Syzygium stapfianum and Syzygium subdecussatum, FZ3 were represented by Syzygium leptostemon, Wikstroemia polyantha and Syzygium napiforme and FZ4 were represented by Syzygium napiforme, Decaspermun parviflorum and Litsea machilifolia. Similarly for family, FZ1 were represented by Podocarpaceae, Guttiferae and Rosaceae, FZ2 by Myrtaceae, Fagaceae and Thymelaeaceae, FZ3 by Myrtaceae, Fagaceae and Guttiferae and FZ4 by Myrtaceae, Lauraceae and Fagaceae. The result clearly indicated that family Myrtacaeae and Fagaceae dominated the forests at FZ2, FZ3 and FZ4. The result of the study showed a different set of species combination of dominant and co-dominant, there is no single species dominant and there between these FZ. In addition, the dominant and co-dominant of these four FZ are dominated by 6 species of the family Myrtaceae and the other six species from six different families.

FZ2, FZ3 and FZ3 shared the most common attributes. In these zones, Myrtaceae has the highest number of species, trees, DBH contribution and dominant family with the highest $I_{v}$. In FZ1, family with the highest number of species, trees, DBH contribution and dominant family with the highest $I_{v}$ were Guttiferae and Myrtaceae, Theaceae, Podocarpaceae and Podocarpaceae.

The correlation analysis of the forest attributes in the four FZ of the study area showed the following general trend. Mean BA, biggest tree DBH, percentage of trees with $\mathrm{DBH}>30 \mathrm{~cm}, \mathrm{E}$, mean DBH, $I_{v}$ of dominant species, R, number of family, $I_{v}$ of first co-dominant species, number of species, $H^{\prime}$, estimated density/ha, $I_{v}$ of 2 nd co-dominant species and number of species decrease with increasing altitude. On the other hand, the percentage of small trees with DBH between 10 and $20 \mathrm{~cm}$ decreases with increasing altitude. These results conformed to the finding of previous studies of tropical rain forest by plant ecologists (Adam et al. 2010, Adam et al. 2007, Adam and 
Enning 1996, Mahmud et al. 1992, Adam and Affandi 1993, Soepadmo 1987, Ohsawa et al. 1985, Yamada 1975)

Comparative analysis showed differences in all forest attributes among four forest zones. Correlation analysis showed a distinct decrease of mean BA, biggest tree DBH percentage of trees with $\mathrm{DBH}>30 \mathrm{~cm}, \mathrm{E}$ and $\mathrm{I}_{\mathrm{v}}$ of dominant species with increasing altitude. On the other hand, there is a distinct increase in the percentage of small trees of DBH from $5-20 \mathrm{~cm}$ with increasing altitude.

\section{Acknowledgements}

Authors wish to thank the Malaysian Government for financing this project which includes UKM-OUP-PLW-12-53//2010, UKM-GUP-ASPL-07-06-135, UKM-GUP-ASPL-07-06-136, UKM-ST-08-FRGS-0017-2009 and UKMS' Fraser Hill Research Centre for giving permission to carry out the research.

\section{References}

Adam JH 1997. Altitudinal Zonation of Primary Rain Forest in Bidu-Bidu, Sabah, Malaysia. Sarwak Museun J. Vol. LI, 72: 107-126.

Adam JH 2000. Vegetation of Mt. Murud. Sarawak Museum J. LV 76: 259-282.

Adam JH 2001. Changes in forest community structures of tropical Montane rain forests on the slope of Mt. Trus Madi in Sabah, Malaysia. J. Trop. For. Sci. 13: 76-92.

Adam JH and NM Affandi 1993. Hutan ultrabasik di Sabah, khususnya di Bukit Tawai, Telupid, Sabah. Penerbitan Tak Berkala 8: 1-21.

Adam JH and FL Enning 1996. Altitudinal zonation of tropical rain forest at Danum Valley Research Centre, Sabah, Malaysia. Malaysian J. Sci. 17A: 25-35.

Adam JH, M Abdul Manap, EM Nurulhuda, AH Hafiza and AR Masdahila 2007. Cluster analysis on floristic composition and forest structure of hilly lowland forest in Lok Kawi, Sabah State of Malaysia. Intl. J. Bot. 3(4): 351-358.

Adam JH, I Hairani, AR Othman, KM Mohamad, SNA Tarmidzi, HA Hamid and Z Ali Rahman 2010. Assessment on changes in forest community structure along the slope on Pine Trail, Fraser Hill, Pahang. In: Bio-kejuruteraan Penilaian Ekosistem \& Species 2009, Kesihatan Persekitaran Untuk Kesejahteraan Sejagat, Adam JH, MB Gasim, MA Aizat, Z Sakawi, Er Ah Choy, Z Ali Rahman and N Tambi (Eds), pp. 1-22. Frasers' Hill Research Centre, Univ. Kebangsaan Malaysia, Raub.

Adam JH and A Maimon 2009. General Introduction. In: Bukit Fraser Crown of The Titiwangsa Range, Latiff A, A Maimon, A Norhayati and JH Adam (Eds), pp. 1-8. Bukit Fraser Research Centre, Universiti Kebangsaan Malaysia \& Fraser's Hill Development Corporation, Raub.

Adam JH and A Affandi 2000. Effect of altitude on ultrabasic forest community structure along the slope of Mt. Tawai, Sabah, Malaysia. J. Biosci. 11: 29-39.

Adam JH and M Zahiruddin 2005. Floristic composition of limestone forests at three different elevations in Bau, Kuching, Sarawak. Malaysian J. Biol. Sci. 5: 478-485.

Cintron G and YS Novelli 1984. Method for studying mangrove structure. In: The mangrove ecosystem research methods. Snedakar S and JG Snedakar (Eds), pp. 91-114. UNESCO, United Kingdom.

Damanhuri A 2009. Chapter 3: Flora of Bukit Fraser. The Mosses. In: Bukit fraser crown of the Titiwangsa Range, Latiff A, A Maimon, A Norhayati and JH Adam (Eds), pp. 24-28. Bukit Fraser Research Centre, Universiti Kebangsaan Malaysia \& Fraser's Hill Development Corporation, Raub.

Haja M 2009. Flora of Bukit Fraser: The ferns. In: Bukit fraser crown of the Titiwangsa Range, Latiff A, A Maimon, A Norhayati and JH Adam (Eds), pp. 24-29. Bukit Fraser Research Centre, Univ. Kebangsaan Malaysia \& Fraser's Hill Development Corporation, Raub.

Kochummen KM 1982. Effects of elevation on vegetation on Gunung Jerai, Kedah. FRI-Res. Pamphlet 87: $1-24$. 
Latiff A 2009. Flora of Bukit Fraser. The flowering plant. In: Bukit Fraser Crown of the Titiwangsa Range, Latiff A, A Maimon, A Norhayati and JH Adam (Eds), pp. 17-23. Bukit Fraser Research Centre, Universiti Kebangsaan Malaysia \& Fraser's Hill Development Corporation, Raub.

Ludwig JA and JF Reynolds 1988. Statistical Ecology: A primer on methods and computing. John Wiley, New York.

Muhammad Barzani G., Sahibin A.R., J.H. Adam and A. R. Zulfahmi 2009. The physical environment. In: Bukit fraser crown of the Titiwangsa Range, Latiff A, A Maimon, A Norhayati and JH Adam (Eds), pp. 9-16. Bukit Fraser Research Centre, Universiti Kebangsaan Malaysia \& Fraser's Hill Development Corporation, Raub.

Ohsawa M, PHJ Nainggolan, N Tanaka and C Anwarl 1985. Altitudinal zonation of forest vegetation on Mount Kerinci, Sumatra: with comparisons to zonation in temperate region of East Asia. J. Tropical Ecol. 1: 193-216

Mahmud T, JH Adam and NM Affandi 1992. Analisis pengklusteran hutan Bukit Tawai, Sabah. Persatuan Ekologi Malaysia. Proceeding Malaysian Ecol. Soc. 1: 25-30.

Soepadmo E 1987. Structure, above ground biomass and floristic composition of the Montane forests at Gunung Janing Barat, Ulu Endau, Johore, Malaysia. Malayan Nature J. 41: 275-290.

Yamada I 1975. Forest ecological studies of the Montane forest near Cibodas. Tonan Ajia Kenkyu 13: 402-426.

(Manuscript received on 14 May, 2011; revised on 22 October, 2011) 